\section{SANDRA STANKOVIĆ 1 DEJAN VASOVIĆ NENAD ŽIVKOVIĆ \\ ${ }^{1}$ University of Nis, Innovation Center \\ ${ }^{2,3}$ University of Nis, Faculty of Occupational Safety in Nis \\ ${ }^{1}$ sandra.stankovic.op@gmail.com ${ }^{2}$ dejan.vasovic@znrfak.ni.ac.rs ${ }^{3}$ nenad.zivkovic@znrfak.ni.ac.rs}

\title{
IMPACTS OF EXTREME HYDROLOGICAL EVENTS ON SUSTAINABLE WATER RESOURCES MANAGEMENT AND HUMAN WELL-BEING
}

\begin{abstract}
The aim of this research is to emphasize the impact of extreme hydrological phenomena on the sustainable management of water-related societal needs. Therefore, it provides a definition of extreme hydrological events, as well as a survey of extreme hydrological events in the Republic of Serbia. It also gives a brief overview of Agenda 2030 with particular respect to Sustainable Development Goal (SDG) No 6 and highlights the impacts of extreme hydrological phenomena on the water resources, both from the perspective of the ecosystem and the society. Root-cause analysis and synthesis of data related to extreme hydrological events that occurred in the Republic of Serbia for characteristic years have been used as primary methods. The conclusion highlights the necessity of ensuring sustainable management of water resources in order to achieve the desired state of human well-being, as well as a healthy ecosystem.
\end{abstract}

Keywords: extreme hydrological events, ecosystem services, sustainability, water resources, management

\section{INTRODUCTION}

Water is the source of all life, without which neither humans nor nature would survive. It represents an integral part of the way people live and make a living, and all societies, cities, and cultures are largely shaped by water. This is confirmed by global data, which shows that almost $70 \%$ of water is used for agriculture, around $19 \%$ for industry, including energy production, and $11 \%$ for domestic water use [1]. The mentioned trend is likely to increase in the upcoming years, as it is well known that climate change, population growth, and economic activities are putting enormous pressure on water resources [5]. Besides, short-sighted economic and technical development choices have often led to the destruction of aquatic and water-related ecosystems with negative consequences for water resources [12]. Therefore, it is vital to preserve water-related ecosystems, including wetlands, forests, mountains, aquifers, rivers, and lakes, as they provide social and economic benefits to people. The downturn condition of the ecosystems directly impacts water availability along with other essential services such as biodiversity, flood control, and food production [12]. Table 1 below presents an overview of the main functions, goods, and services that can be applied to specific natural and water-related ecosystems and their correlated ecological structures and processes. The first column contains functions, the second lists the ecological structures and processes underlying these functions and the third column presents a more detailed list with some examples of specific goods and services stemming from these functions (not exhaustive by any means). The table includes only those goods and services that can be used on a sustainable basis [2].
Water regulation, for instance, deals with the influence of natural systems on the regulation of hydrological flows at the earth's surface. This function is different from disturbance prevention because it refers to the maintenance of "normal" conditions in watersheds and not to the prevention of extreme events. [2]

Table 1. Function, goods, and services of specific natural and water-related ecosystems

\begin{tabular}{|c|c|c|}
\hline $\begin{array}{l}\text { Functions } \\
\text { (Regulation } \\
\text { Functions) }\end{array}$ & $\begin{array}{c}\text { Ecosystem } \\
\text { processes and } \\
\text { components }\end{array}$ & $\begin{array}{c}\text { Goods and } \\
\text { services } \\
\text { (examples) }\end{array}$ \\
\hline $\begin{array}{l}\text { 1. Water } \\
\text { regulation }\end{array}$ & $\begin{array}{l}\text { Role of land cover } \\
\text { in regulating } \\
\text { runoff and river } \\
\text { discharge }\end{array}$ & $\begin{array}{cl}1.1 & \begin{array}{l}\text { Drainage and } \\
\text { natural } \\
\text { irrigation }\end{array} \\
\mathbf{1 . 2} & \begin{array}{l}\text { Medium for } \\
\text { transport }\end{array}\end{array}$ \\
\hline 2. Water supply & $\begin{array}{l}\text { Filtering, } \\
\text { retention, and } \\
\text { storage of } \\
\text { freshwater (e.g. in } \\
\text { aquifers) }\end{array}$ & $\begin{array}{l}\text { Provision of water } \\
\text { for consumptive } \\
\text { use (e.g. drinking, } \\
\text { irrigation, and } \\
\text { industrial use) }\end{array}$ \\
\hline $\begin{array}{l}\text { 3. } \text { Climate } \\
\text { regulation }\end{array}$ & $\begin{array}{l}\text { Influence of land } \\
\text { cover, boil, and } \\
\text { mediated } \\
\text { processes on } \\
\text { climate }\end{array}$ & $\begin{array}{l}\text { Maintenance of a } \\
\text { favourable climate } \\
\text { (temp., } \\
\text { precipitation, } \\
\text { etc.), for example, } \\
\text { human habitation, } \\
\text { health, cultivation }\end{array}$ \\
\hline $\begin{array}{l}\text { 4. Disturbance } \\
\text { prevention }\end{array}$ & $\begin{array}{l}\text { Influence of } \\
\text { ecosystem } \\
\text { structure on } \\
\text { dampening } \\
\text { environmental } \\
\text { disturbances }\end{array}$ & $\begin{array}{l}\text { 4.1 Storm } \\
\text { protection } \\
\text { 4.2 Flood } \\
\text { prevention (e.g. } \\
\text { by wetlands and } \\
\text { forests) }\end{array}$ \\
\hline
\end{tabular}


Water also represents the medium through which the impacts of climate change will be felt, in addition to air temperature. A close connection between water and climate variability is critical for the state of all ecosystems and their services, human communities, and human behaviour. Many of the implications of climate change play themselves out through the water system in terms of extreme flooding or extreme drought [5]. These extreme climatic events cause negative effects on the natural environment, habitats, and the socioeconomic development around the world, including Serbia.

\section{DEFINING EXTREME (HYDROLOGICAL) EVENTS}

Extreme events have been a topic of interest for scientists and managers in recent years because of their potential to induce extensive damage and impacts on environmental, social, and technical systems. What defines an extreme event differs across various studies and disciplines, where they are usually interchanged with their impacts [3]. Figure 1 shows a transdisciplinary scheme for conceptualizing extreme events, their impacts, and the response to them. It also contains the nexus between impacts and events and between impacts and subsequent responses, including the various terms used across different disciplines to explain these periods, and the highlighted examined disciplines, indicating areas of overlap and differences [3].

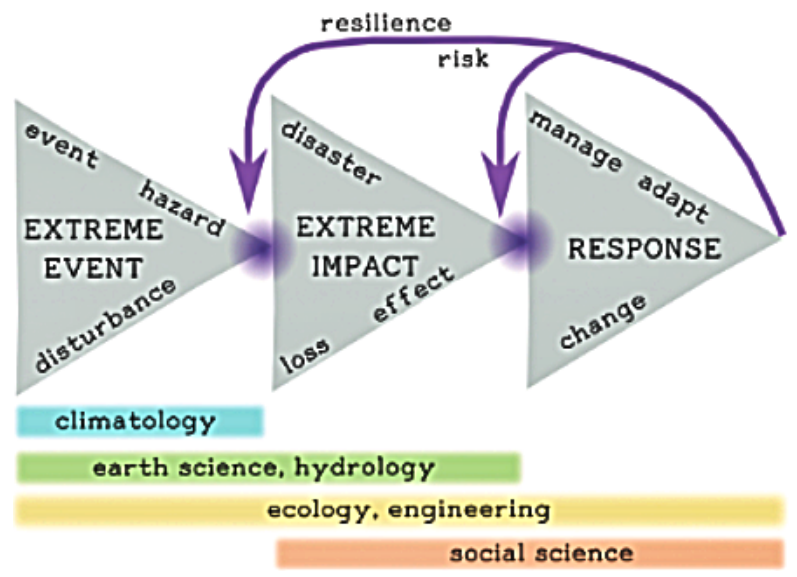

Figure 1. Transdisciplinary framework for conceptualizing extreme events, their impacts, and the response to them (Source:

https://agupubs.onlinelibrary.wiley.com/doi/pdf/10.100 2/2017EF000686)

The Intergovernmental Panel on Climate Change (IPCC) defines extreme weather or an extreme climate event as "an event that is rare at a particular place and time of year". The IPCC Fifth Assessment Report also concluded that strong evidence exists globally for increases in certain extremes, such as heavy precipitation or extreme droughts, since 1950 [4].

The greatest threat to ecosystems and humans will be manifested locally, through changes in regional extreme weather and climate events. The European continent, for instance, is especially exposed to changes in the frequency and intensity of extreme events such as heatwaves, heavy precipitation, extreme droughts, and wind storms, as seen in recent years. [5] Serbia is a good example of understanding the impact of global and regional climate change on the water balance. A flow rate of approximately 16 billion $\mathrm{m}^{3}$ of domicile water is formed in Serbia, which amounts to only $8 \%$ of the total run-off from Serbia. The situation is even worse when taking into account the spatial and temporal uneven flow, and particularly the long durations of low water where water is needed the most, especially in the Morava region [6].

\section{THE MOST COMMON EXTREME CLIMATE EVENTS IN THE REPUBLIC OF SERBIA FOR SPECIFIC YEARS}

In the period from 1900 to 1940 , there were hundreds of natural disasters every ten years, from 1960 to 1970 there were 650, and from 1980 to 1990 there were up to 2,000, while in the ten-year period from 1990 to 2000, the number of disasters rose to 2,800 [7]. The trend shows that the number of extreme and emergency situations is increasing annually, which is one of the reasons why the economic costs have tripled. This is also confirmed by data for the previous two decades.

Record-breaking extreme weather was the hallmark of 2018 in the Republic of Serbia, compared to 2017, which was normal and dry in most of the country $[8,9]$. In the year of climate records, recorded measurements in Serbia reveal that 2018 was the warmest year in the history of the country's meteorological measurements, having the warmest spring, the warmest April, and the warmest year in terms of minimum temperature [9]. The mean value of air temperature was $12^{\circ} \mathrm{C}$, which makes 2018 an extremely warm year in the period from 1951 until today [10]. Unlike for temperature, the estimates of changes in precipitation are more complex, and it is expected to increase in Europe. However, there is an agreement that there will be a marked drop in summer precipitation in the wide area of the Mediterranean and the Balkan Peninsula. The year 2018 had an average amount of rain in most parts of Serbia, unlike in 2017, which was normal and dry. Very rainy and extremely rainy weather was recorded in the western, north-eastern, and central parts of Serbia, as shown in Figure 2. The dark green and dark brown colours in Figure 2 correspond to extreme events - extreme precipitation and extreme drought. 


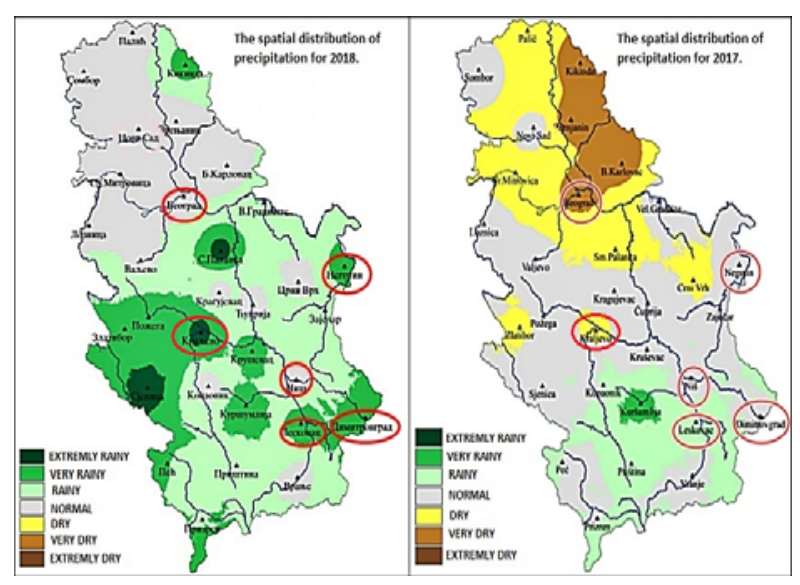

Figure 2. Map of the spatial distribution of precipitation for 2017 and 2018

Such extreme changes will have a negative effect on the volume of annual water balance, because previous studies have shown that, on average, about $75 \%$ of precipitation is lost through evapotranspiration from the territory of Serbia, i.e. only $25 \%$ through precipitation. [6] It should be noted that the quantity and quality of the surface water in the basin depend on natural factors, the most influential of which are: geographical location, relief of the land, air temperature, precipitation, and various anthropogenic influences. Water resource abundance, as a feature of a particular catchment area, represents the best indicator of the average flow. Figures 3 and 4 show the sum of monthly rainfall in millimeters for 2017 and 2018.

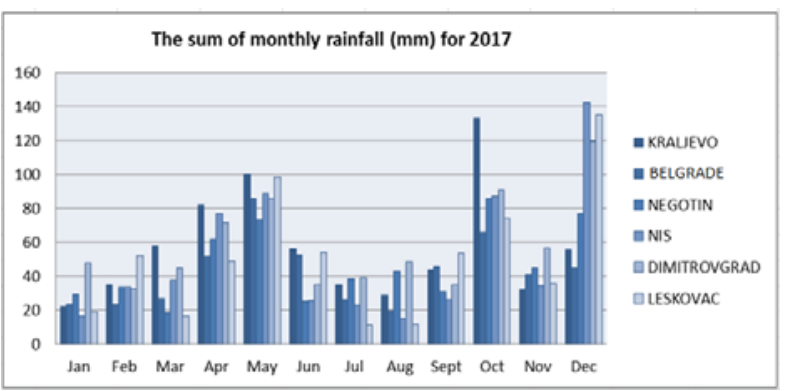

Figure 3. The sum of monthly rainfall showed in millimeters for 2017

The beginning of 2017 saw a dry period, which is why the winter season 2016/2017 was declared the fourth driest, but without extreme hydrological phenomena. Spring and autumn months were warm and rainy, except in October, when extreme rainfall was recorded in Kraljevo. Extreme precipitation was also registered in December in Nis, Leskovac, and Dimitrovgrad, while no extreme hydrological phenomena were registered in Belgrade and Negotin.

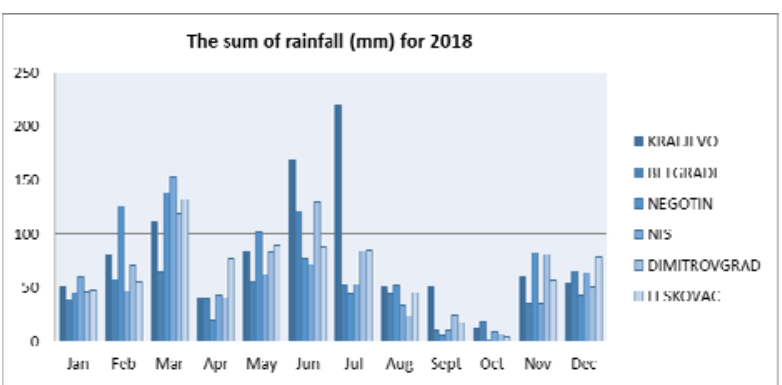

Figure 4. The sum of monthly rainfall showed in millimeters for 2018

During 2018, the rainiest months were February, March, June, and July. Even though spring was declared as the warmest in Serbia since 1951, extreme precipitation was recorded in Negotin, Nis, Leskovac, and Dimitrovgrad in March, while in Kraljevo it was recorded only in July. The extreme drought periods were recorded in Negotin in April and October, in Leskovac in October, while in Belgrade there were no extreme hydrological phenomena.

\section{OVERVIEW OF AGENDA 2030 - SDG 6}

Compared to the Millennial Declaration (MD) from 2000, which consisted of 8 goals and 21 targets relevant to low-income countries, which were supposed to be implemented by 2015, the Agenda 2030 itself consists of 17 SDGs, 169 targets, and 230 indicators that will shape the world until 2030. This Agenda includes new issues compared to the MDGs, such as climate change, sustainable consumption and innovations. Highlighting water targets, there were 2 water and sanitation targets under MDG 7, whereas there are 8 water and sanitation targets under SDG 6 and 1 under SDG 11, as well as 11 core indicators on water and sanitation (Fig. 5) [11].

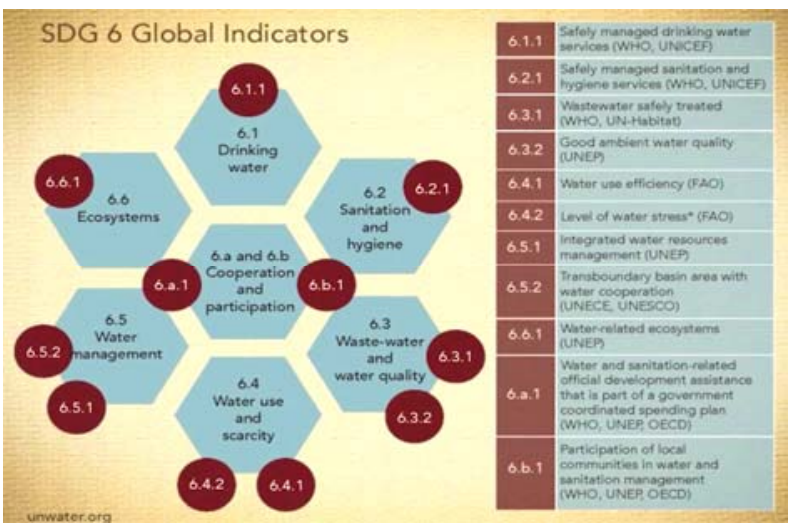

Figure 5. Sustainable development goal 6 - targets and indicators (Source: EPA H2020 SC5 Info Day: United Nations Sustainable Development Goals - Federico Properzi, UN-Water)

As shown in Figure 5, SDG 6 has a broad concept of implementing sustainable water resources management, ensuring availability and sustainable management of water and sanitation for all. It aims to look at the whole water cycle including environmental aspects, such as 
pollution reduction and water scarcity, social aspects in drinking water and sanitation, and economic aspects linked, for instance, to water monitoring and integrated water management. Protection and use of water is a problem present in all SDGs.

Target 6.5 as the most comprehensive step towards SDG, addresses the integrated water resources management (IWRM) and the objective to implement IWRM at all levels, including the transboundary cooperation as suitable in transboundary river basins or groundwater basins. Target 6.6 aims to protect and restore water-related ecosystems so that they can continue to provide benefits to society by halting their degradation and destruction due to climate changes and extreme phenomena. Based on that, indicator 6.6.1 will be used to monitor management concerning the target by tracking changes in the extent of water-related ecosystems over time. This indicator calls for data to be collected on the spatial extent of water-related ecosystems and the quantity and quality of water within them. [11] Although reservoirs have value in helping people to provide consistent water supplies, transitioning from some natural ecosystems to an artificial water body can make ecosystems unsustainable.

Serbia is implementing SDG 6 trough transposition of the two key European directives - the Drinking Water Directive and the Urban Waste Water Treatment Directive. The Drinking Water Directive deals with the quality of water intended for human consumption by protecting human health from the adverse effects of any contamination of water. The purpose of the Urban Waste Water Treatment Directive is to protect the environment from the adverse effects of urban wastewater discharges and emissions from certain industrial sectors. The strategic document in this field, aimed at the implementation of SDG target 6.5, is the Water Management Strategy on the territory of the Republic of Serbia for the $2016-2034$ periods. For the development and efficient water management in the next 20 years, it is necessary to invest 21.7 billion euros, and $43 \%$ of this investment is imperative for water protection ( 7.7 billion euros).

In addition to SDGs, the importance of strategic planning and management in the context of extreme events, climate changes, and urbanization has also been underscored in other international policy frameworks, such as the Sendai Framework for Disaster Risk Reduction 2015-2030, the Paris climate agreement from 2015, as well as the New Urban Agenda. The Sendai Framework is aimed at preventing new and reducing the existing disaster risks, with seven targets and four priorities for action. While the Paris agreement is aimed at tackling climate change and adapting to its effects, the New Urban Agenda represents a shared vision for a better and more sustainable future for both developing and developed countries.

\section{ASPECTS OF VULNERABILITY, EXPOSURE, AND IMPACTS}

The origin, scope, and duration of the natural disasters in most cases cannot be predicted in advance, but for certain phenomena, based on experience, statistics, and modeling methods, and given the location of occurrence, assumptions can be made regarding their occurrence. For various extreme hydrological events, the following facets are examined on a regional basis:

- Exposure of humans and their activities to given extremes;

- The vulnerability of whatever is exposed to the extreme event; and

- The resulting impacts.

Table 2 shows the estimated damage in time-dependent sectors in Serbia. While there is no doubt that the Serbian economy suffers significant losses in material goods, atmospheric hazards also cause losses of human lives [7].

Table 2. Estimated losses in time-dependent sectors

\begin{tabular}{|c|c|c|}
\hline \multirow[b]{2}{*}{$\begin{array}{l}\text { Sector/adverse } \\
\text { weather events }\end{array}$} & \multicolumn{2}{|c|}{ Estimated losses in sectors } \\
\hline & $\begin{array}{l}\text { Average } \\
\text { annual } \\
\text { economic } \\
\text { losses in } \\
\text { millions of } \\
\text { dinars }\end{array}$ & $\begin{array}{c}\text { Average } \\
\text { annual } \\
\text { losses of } \\
\text { human lives }\end{array}$ \\
\hline Agriculture/floods & $\begin{array}{l}\text { From } 3,100 \text { to } \\
8,500\end{array}$ & $\begin{array}{l}\text { A few to a } \\
\text { dozen }\end{array}$ \\
\hline $\begin{array}{c}\text { Water } \\
\text { management/floods }\end{array}$ & around 1,960 & / \\
\hline $\begin{array}{l}\text { Agriculture/city, } \\
\text { strong and heavy } \\
\text { rains, strong winds }\end{array}$ & around 7,316 & $\begin{array}{l}\text { A few to a } \\
\text { dozen, incl. } \\
\text { from } \\
\text { lightning }\end{array}$ \\
\hline $\begin{array}{l}\text { Agriculture/drought, } \\
\text { frosts }\end{array}$ & around 4,000 & No losses \\
\hline $\begin{array}{c}\text { Production of } \\
\text { energy (heat) } \\
\text { /extremely low air } \\
\text { temperatures }\end{array}$ & around 716 & $\begin{array}{l}\text { A few to a } \\
\text { dozen }\end{array}$ \\
\hline $\begin{array}{l}\text { Road maintenance } \\
\text { /snow, ice, freezing }\end{array}$ & around 3,500 & / \\
\hline \multicolumn{3}{|c|}{$\begin{array}{l}\text { Annual human losses on highways, regional and local } \\
\text { roads caused by bad weather range from } 105 \text { to } 131\end{array}$} \\
\hline $\begin{array}{l}\text { Commercial air } \\
\text { transport }\end{array}$ & from 54 to 72 & / \\
\hline TOTAL & $\begin{array}{l}\text { from } 16,648 \text { to } \\
\quad 48,572\end{array}$ & $\begin{array}{l}\text { From a few } \\
\text { to } 160\end{array}$ \\
\hline
\end{tabular}

As a result of extreme hydrological phenomena, flash floods are characterized by a short duration, leaving behind the ruins, or closed roads for up to several weeks [7]. In case of extreme atmospheric precipitation, there is the risk of flooding of settled areas from rivers and streams, as well as due to inadequate maintenance of the drainage channels 
around and within the areas. Furthermore, a large number of landslides could be activated.

In addition, short-sighted economic and technical development choices have often contributed to the destruction of aquatic and water-related ecosystems with negative consequences for the water resources.

\section{CONCLUSION}

Sustainable water resources management requires a comprehensive understanding and close consideration of ecosystem functions and interactions between all ecosystems. The ecosystem services provided by nature through lakes, rivers, wetlands, and forests can help secure urban resilience, human well-being and health, as well as biodiversity, and employment.

Extreme hydrological events, such as floods and droughts, play important roles in natural ecosystems and are a major concern for society, with significant impacts on the economy, ecosystem health, and services, as well as human health. These extremes are the primary manifestations of climate change for most people. The protection and sustainable management of water-related ecosystems are essential to meeting all SDGs, along with other measures of adapting to climate change.

It is necessary to learn how to manage water more prudently, fairly, and sustainably to avoid a serious water crisis. An active policy of disaster risk reduction and efficient emergency response can greatly reduce the number of human casualties and material damage. Information about hydrological data and forecasts, warnings and information about high and low water and ice conditions, should be promptly distributed to all participants in the system of water resource management, as well as to the media, in order to reduce the negative impacts of extreme events.

\section{REFERENCES}

[1] Food and Agriculture Organization of the United Nations (FAO), AQUASTAT Main database, Water uses, 2016.

[2] R. S. de Groot, M. A. Wilson, R. M.J. Boumans:” A typology for the classification, description and valuation of ecosystem functions, goods and services", Ecological Economics, Vol. 41, 2002, pp. 393-408.

[3] L. E. McPhillips, H. Chang, M. V. Chester: "Defining extreme events: a cross-disciplinary review", AGU Earth's Future, 2018, pp. 441-455

[4] Special Supplement to the Bulletin of the American Meteorological Society, Explaining extreme events of 2013 from a climate perspective,

[5] M. Beniston, David B. Stepenson, Ole B. Christiansen: "Future extreme events in European climate: an exploration of regional climate model projections", Climatic Change, Vol. 81, 2007, pp. 71-95.
[6] N. Veljkovic, T. Popovic, M. Jovicic: "Climate impact factors on quality of Pomoravlje catchments rivers: ${ }_{S} S W Q I_{R B}$ analysis method", Voda i sanitarna tehnika, no. 5-6, 2012, Belgrade.

[7] The National Strategy for protection and rescue in emergency situations "Official Gazette" no. 86/2011.

[8] Republic Hydro-meteorological Service of Serbia: "Annual Bulletin for Serbia for 2017 year", 2018, Belgrade

[9] Republic Hydro-meteorological Service of Serbia: "Annual Bulletin for Serbia for 2018 year “, 2019, Belgrade.

[10] M. Gocic, S. Trajkovic: „Drought characterisation based on Water Surplus Variability Index", Water Resources Management, Vol. 28, No 10, 2014, pp. 3179-3191, doi: 10.1007/s11269-014-0665-4.

[11] UN Water, Sustainable Development Goal 6 Synthesis Report 2018 on Water and Sanitation, 2018, New York.

[12] UN Water, Clean water and sanitation - Progress on water-related ecosystems, 2018, New York.

\section{ACKNOWLEDGEMENTS}

The presented research is a part of the projects "Development of new information and communication technologies, based on advances mathematical methods, with applications in medicine, telecommunications, power systems, protection of natural heritage and education" (III 44006) and "Research and development of energy efficient and environment friendly polygeneration systems based on renewable energy sources utilization" (III 42006), under the auspices of the Ministry of Education, Science and Technological Development, Republic of Serbia, as well as project of Serbian Academy of Sciences and Arts, Branch in Niš "Integral approach to stormwater management in urban catchment areas in the south-east Serbia region", No: O-15-18.

\section{BIOGRAPHY of the first author}

Sandra Stanković was born in Nis, Serbia, in 1991. She received her master's degree in Environmental Protection Engineering, study programme Communal System Management at the Faculty of Occupational Safety in Niš, and is currently a PhD student in Environmental

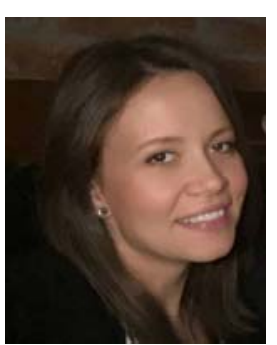
Engineering at the University of Nis, at the same faculty.

Her main areas of research include, but are not limited to, water resources management, measures of climate change adaptation, green infrastructure, etc. She currently works as a project officer at the Innovation Center of the University of Nis 


\section{UTICAJ EKSTREMNIH HIDROLOŠKIH DOGAĐAJA NA ODRŽIVO UPRAVLJANJE VODNIM RESURSIMA I BLAGOSTANJE DRUŠTVA}

\section{Sandra Stanković, Dejan Vasović, Nenad Živković}

Rezime: Osnovni cilj ovog rada je da istakne uticaj ekstremnih hidroloških pojava na održivo upravljanje vodnim resursima koji su neophodni društvu. Stoga, rad definiše ekstremne hidrološke pojave, kao i pregled ekstremnih hidroloških događaja sa posebnim osvrtom na stanje u Republici Srbiji. U ovom radu je takođe izvršena analiza Agende 2030 sa posebnim osvrtom na cilj održivog razvoja (SDG) broj 6 i istaknut je uticaj ekstremnih hidroloških pojava na održivo upravljanje vodnim resursima, bilo sa stanovišta potreba društva ili ekosistema. Uzročno-posledična analiza i sinteza podataka o ekstremnim hidrološkim događajima tokom karakterističnih godina u Republici Srbiji predstavljaju osnovu korišćene metodologije. Na kraju rada se ukazuje na neophodnost obezbeđivanja održivog upravljanje vodnim resursima u svim uslovima, radi očuvanja ekosistema i zadovoljenja potreba društva.

Ključne reči: ekstremni hidrološki događaji, ekosistemske usluge, održivi razvoj, vodni resursi, upravljanje. 